\title{
Kunnskapsbasert politikkutforming
}

\author{
Atle Fretheim ${ }^{1,2}$ \\ 1) Seksjon for global helse, Nasjonalt kunnskapssenter for helsetjenesten \\ 2) Institutt for helse og samfunn, Universitetet i Oslo \\ E-post: atle.fretheim@kunnskapssenteret.no Telefon: 91649828
}

\begin{abstract}
SAMMENDRAG
Kunnskapsbasert politikkutforming er en tilnærming til politiske beslutninger der en søker å benytte den beste, tilgjengelige forskningsbaserte kunnskapen - samtidig som det tas høyde for lokale verdier og preferanser, og utøves politisk skjønn. Det er viktig å erkjenne at forskningsbasert kunnskap kun er én av mange faktorer som kan innvirke på politiske beslutninger.

Hva slags kunnskap som er relevant avhenger av problemstillingen. I politiske beslutningsprosesser vil det ofte være aktuelt å innhente informasjon om omfanget av et problem, og om problemets årsak. Når det gjelder spørsmål om hvorvidt et tiltak virker, vil resultater fra eksperimentelle eller kvasi-eksperimentelle studier være de mest relevante å ta med $\mathrm{i}$ vurderingen, herunder forskning utført utenfor vårt eget land. Det foreligger mange systematiske oversikter om effekt av tiltak innen organisering av helsetjenester, finansieringsordninger, strategier for kvalitetsforbedring osv.

Effektstørrelser fra tidligere utprøvninger av et tiltak er viktig informasjon, men langt fra tilstrekkelig til å avgjøre om tiltaket er verdt satse på. En må også søke å forstå hvilke faktorer som bidrar til at tiltaket fungerer etter intensjonen, eller ei. Her vil blant annet kvalitative evalueringer være en viktig informasjonskilde.

Det er ofte uklart hvorvidt de motstridende standpunkt som forfektes i en politisk debatt skyldes sprikende virkelighetsoppfatninger eller ideologiske motsetninger. Transparent og systematisk bruk av forskningsbasert kunnskap kan gjøre dette skillet tydeligere, og bidra til en mer konstruktiv politisk debatt, i tillegg til at et bedre beslutningsgrunnlag vil gi bedre beslutninger - må vi håpe.
\end{abstract}

Fretheim A. Evidence-informed policymaking. Nor J Epidemiol 2013; 23 (2): 205-210.

\section{ENGLISH SUMMARY}

Evidence-informed policymaking is an approach to policy decisions where the best available research evidence is used - while taking local values and preferences into account, and making political judgments. It is necessary to acknowledge that evidence is only one of several factors that can influence policy decisions.

What type of evidence that is relevant depends on the type of issue that is being addressed. In political decision making, questions are often raised about the size of a problem, and what the likely causes are. Concerning whether a strategy or intervention is likely to be effective in addressing an identified problem, findings from experimental and quasi-experimental studies will be the most relevant types of evidence, including research conducted outside one's own geographic area. Many systematic reviews address effects of interventions about the organisation of health care services, financial arrangements, quality improvement strategies etc.

The effect estimates from previous evaluations of an intervention is important information, but far from sufficient to decide whether the intervention should be pursued. One also needs to understand the factors that can contribute to successful implementation and lead to the intended results. For this, qualitative evaluations may be an important source of information.

It is often not clear whether contradicting views in a political debate are due to differences in perceptions of reality, or ideological differences. Transparent and systematic use of research evidence may make this distinction clearer and thus contribute to more constructive political debates, in addition to leading to better policy decisions - hopefully.

This is an open access article distributed under the Creative Commons Attribution Licence, which permits unrestricted use, distribution, and reproduction in any medium, provided the original work is properly cited.

\section{INNLEDNING}

Det er tilsynelatende ukontroversielt å mene at politiske beslutninger bør være fundert på beste tilgjengelige kunnskap. Kunnskapsbasert er blitt et honnørord, ikke minst innen offentlig forvaltning. På tross av det: Det er betydelig uenighet om hva kunnskapsbasert politikkutforming er, og bør være - både i teori og i praksis.

Det kan hevdes at forskningsbasert kunnskap har en meget beskjeden plass i politiske prosesser, som i stor grad preges av interessekamp og motstridende verdivalg. Politikere på høyresiden i norsk politikk er mer opptatt av prinsippet om foreldreansvar enn hva eventuell forskning måtte vise om gevinster av gratis skolemat. Og venstresiden blir neppe velvillig innstilt til bruk av private firmaer i hjemmesykepleien, selv om det skulle vise seg å føre til bedre og billigere tjenester. Ideologiske standpunkter veier ofte tyngre i politiske beslutninger enn forskningsbasert kunnskap - uten at det nødvendigvis er noe galt $i$ det. 
Når det vises til forskningsresultater i politiske debatter er det stort sett snakk om forskning som underbygger det prinsipielle standpunktet debattantene hadde i utgangspunktet. Det er få kjente eksempler på at ny forskningsbasert kunnskap har fått politikere til å endre standpunkt.

Men selv om forskningsbasert kunnskap kanskje blir tillagt liten vekt i politisk arbeid, går det an å mene at dette burde vært annerledes. Mange byråkrater arbeider hardt og samvittighetsfullt for å framskaffe et solid kunnskapsgrunnlag, herunder forskningsbasert kunnskap, for å bidra til gode politiske beslutningsprosesser. Den hyppige bruken av ordet "kunnskapsbasert" i politiske taler og dokumenter kan tolkes som et uttrykk for at også politikerne har en ambisjon om at kunnskap skal ha en viktig plass i politikkutformingen. For eksempel, da Stortinget debatterte alkoholpolitikken 15. januar 2013 (se figurene 1-4).

I denne sammenheng brukes begrepet kunnskapsbasert med samme betydning som det engelske evidence-based, selv om kunnskap og evidence strengt tatt ikke er helt ensbetydende. Med evidence menes her dokumentasjon eller forskningsbasert kunnskap.

\section{KUNNSKAPSBASERT PRAKSIS}

Det var innen klinisk medisin at begrepet evidencebased først ble introdusert og fikk rotfeste, tidlig på 1990-tallet (1). Forkjemperne av kunnskapsbasert medisin tok til orde for at beslutninger om behandlingstiltak i større grad skulle bygge på beste tilgjengelige kunnskap.

Kunnskapsbasert medisin er en praktisk tilnærming for å oppnå bedre beslutninger i møtet mellom helsearbeider og pasient: en kunnskapsbasert praksis. I tillegg til at beslutninger bør bygge på den beste tilgjengelige kunnskap, legges det stor vekt på at pasientens egne verdier og preferanser også er en vesentlig del av beslutningsgrunnlaget. Dessuten at helsearbeiderens kliniske erfaring er viktig for gode beslutninger. En av nestorene innen evidence-based medicine, David Sackett, formulerte det slik: "Evidence-based medicine is the integration of best research evidence with clinical expertise and patient values" (2).

Tilsvarende begrepsbruk spredte seg raskt til mange andre fagområder: Evidence based education, evidence based social work, evidence based policing, evidence based policy osv.

Om vi legger til grunn at kunnskap bør ha en sentral plass i politiske beslutningsprosesser, står vi likevel overfor flere kontroversielle spørsmål, blant annet:

- Hva slags typer kunnskap bør tillegges størst vekt?

- Hva er forholdet mellom kunnskap, verdivalg og ideologi?

\section{HVA SLAGS TYPER KUNNSKAP BØR TILLEGGES STØRST VEKT?}

Hva slags kunnskap som er relevant avhenger naturligvis av hva som er problemstillingen. I politiske beslut- ningsprosesser vil det ofte være aktuelt $\stackrel{\circ}{\text { innhente }}$ informasjon om omfanget av et problem $(3,4)$ - hvor mange norske ungdommer røyker daglig? Hvor mange skades i trafikken? Epidemiologisk forskning med data fra spørreskjemaundersøkelser og registre kan gi oss gode svar på slike spørsmål, og da i første rekke studier som er utført i det aktuelle geografiske området hvor mange som røyker eller skades i trafikken i USA eller Kina har begrenset interesse for norsk politikkutforming.

Det kan også være aktuelt å innhente informasjon om hva ungdommene mener er de viktigste grunnene til at de begynner å røyke eller hvorfor fartsgrenser ikke overholdes. Her er kvalitative intervjuer og spørreskjemaundersøkelser gode kunnskapskilder.

Når det gjelder spørsmål om i hvilken grad et tiltak virker, vil eksperimentelle eller kvasi-eksperimentelle studier være de mest relevante (5). Og her kan det være grunn til å ta inn over seg forskning som er utført utenfor vårt eget land: Hvis amerikanerne eller kineserne har lykkes med å redusere røykingen eller antall trafikkskadde, kan det være noe å lære av - også for oss.

\section{Randomiserte kontrollerte forsok og systematiske oversikter}

Pionerene innen evidence-based medicine var særlig opptatt av kunnskap som gjaldt effekt av tiltak, og la stor vekt på resultater fra kliniske randomiserte kontrollerte forsøk. Dette som motsats til å stole blindt på autoriteter, usystematisert klinisk erfaring, eller funn fra basalforskning. Og den beste tilgjengelige kunnskap om et effektspørsmål fås ved å oppsummere resultatene fra alle relevante randomiserte forsøk i en systematisk oversikt (systematic review).

Gjennom The Cochrane Collaboration er det produsert flere tusen systematiske oversikter om effekt av tiltak i helsetjenesten. Flertallet av disse dreier seg om kliniske tiltak, men det er også mange Cochraneoversikter som omhandler effekt av tiltak innen organisering, finansiering, kvalitetsforbedring osv. Søsterorganisasjonen The Campbell Collaboration sørger for at det utarbeides systematiske oversikter om effekt av tiltak på sosial-, utdannings- og justisfeltet.

Ideen om å bruke resultater fra randomiserte studier som kunnskapsgrunnlag når det fattes beslutninger om medisinsk behandling er veletablert, og var det lenge før evidence-based medicine ble lansert: Siden 1970tallet har det vært stilt krav om resultater fra slike studier før godkjenning av nye legemidler. Men for andre typer tiltak enn legemidler har det vært vanskeligere å få gjennomslag for verdien av randomiserte forsøk, og kanskje særlig på områder der det er snakk om intervensjoner som er mer komplekse: Det er lettere å få gehør for at virkningene av enkle medisinske tiltak (legemidler) kan evalueres i randomiserte forsøk, enn at sammensatte, sosiale intervensjoner innen barnevern og kriminalomsorg bør prøves ut på samme måte. Dessuten er det en del områder der det kan være vanskelig å gjennomføre denne type eksperimenter. En 


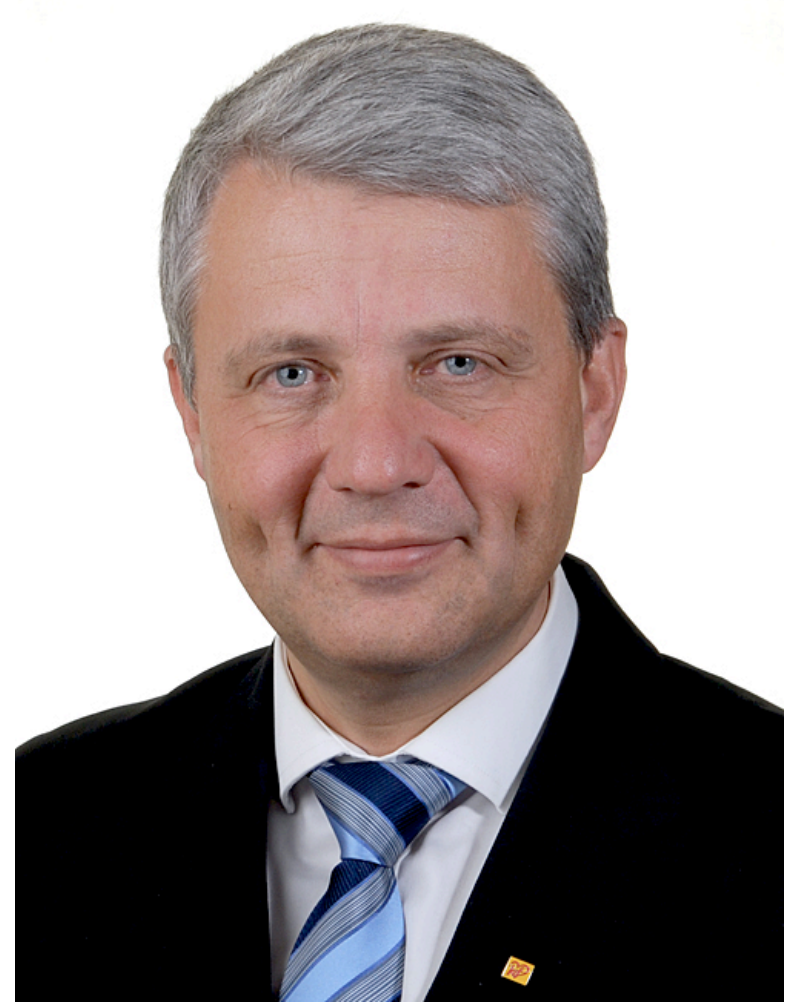

Figur 1. Dagfinn Høybråten $(\mathrm{KrF})$ i alkoholdebatt på Stortinget 15. februar 2013: "Etter min mening har befolkningen rett til å forvente en kunnskapsbasert utforming av alkoholpolitikken." (Foto: CStortingsarkivet).

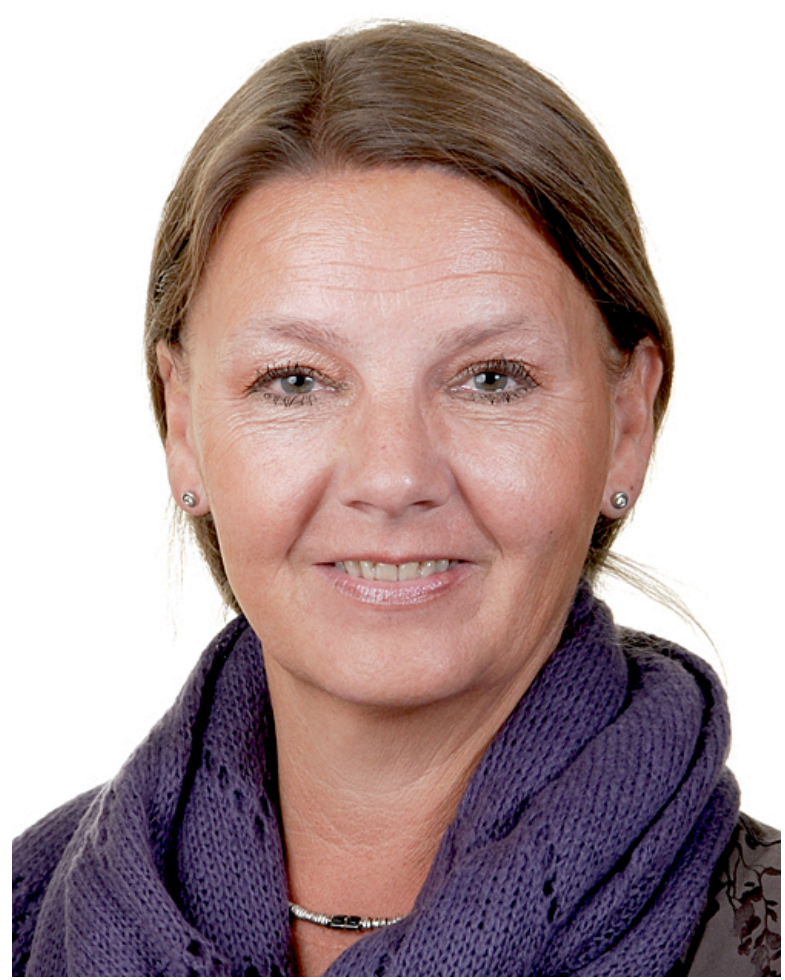

Figur 2. Ingjerd Schou $(\mathrm{H})$ i alkoholdebatt på Stortinget 15. februar 2013: "viktig for Høyre at politikken er kunnskapsbasert." (Foto: CStortingsarkivet).

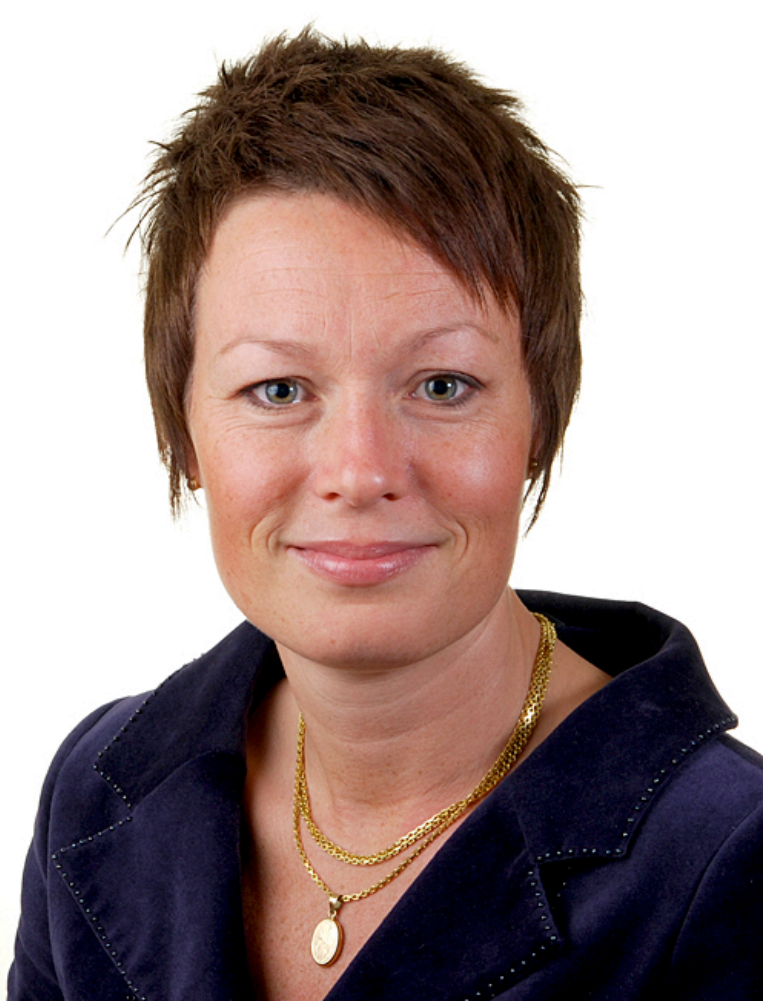

Figur 3. Line Henriette Hjemdal $(\mathrm{KrF})$ i alkoholdebatt på Stortinget 15. februar 2013: "For det første må vi ha en kunnskapsbasert politikk." (Foto: OStortingsarkivet).

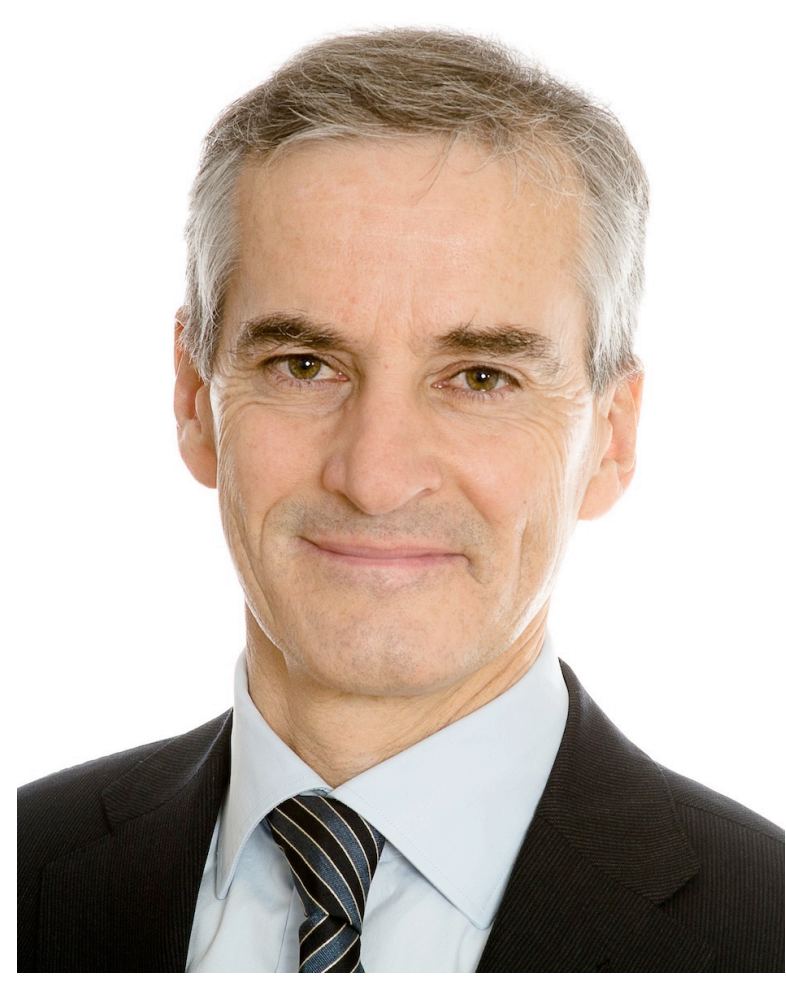

Figur 4. Jonas Gahr Støre (helseminister, Ap) i alkoholdebatt på Stortinget 15. februar 2013: "Hun ber om kunnskapsbasert politikk. Hun ber om at man eksperimenterer med løsninger. Begge deler er jeg for.” (Foto: Bjørn Studal). 
loddtrekning blant drapsmenn for å studere virkningene av kort versus lang fengselsstraff kan neppe gjennomføres.

\section{Kritikk av eksperimentell metode}

Noen kritikere mener at andre kvantitative evalueringsmetoder bør veie like tungt som randomiserte forsøk, også når det er snakk om å vurdere effekt av tiltak (6). Eksempler på alternative studiedesign er kohortstudier, økologiske studier, før-og-etter sammenlikninger, økonometriske metoder og modellering. Uenigheten dreier seg blant annet om i hvilken grad en er bekymret for at ikke-randomiserte studier vil gi misvisende resultater som følge av feilkilder - i første rekke seleksjonsskeivhet: Ved, for eksempel, å sammenlikne kommuner med og uten restriktiv alkoholpolitikk kan vi neppe si noe som helst om hvorvidt den ene eller andre strategien fører til mer eller mindre drikking - kommunene er sannsynligvis så forskjellige $\mathrm{i}$ utgangspunktet at en slik sammenlikning vil være meningsløs. Men i andre tilfeller kan ikke-randomiserte studier ha stor verdi: Dersom noen kommuner vedtar en dramatisk endring $i$ sin skjenkepolitikk, og dette - nærmest over natta medfører en dramatisk nedgang i antall voldsepisoder på lørdagskveldene, er det rimelig å tro på en årsakssammenheng.

Noen er skeptiske til bruk av randomiserte kontrollerte forsøk ved utprøving av komplekse tiltak fordi det - i motsetning til for legemidler - ofte vil være vanskelig å standardisere tiltaket (7). For eksempel vil iverksetting av en ny reform i helsesektoren gjerne bli gjennomført på forskjellig vis og i varierende grad fra sykehus til sykehus, og dermed blir det meningsløst å forsøke å trekke noen generell slutning om virkningene av tiltaket - hevdes det. Det kan dessuten være vanskelig å samle inn data som er gode nok til å vurdere virkningene av denne type tiltak (7).

Andre kritikere er generelt skeptiske til kvantitative evalueringer, som tross alt kun bidrar med svar på hva resultatet ble i én aktuell kontekst, i ett aktuelt tidsrom: En amerikansk studie fra 1960-tallet om virkningene av omsorgsovertakelse av barn sier lite eller ingenting om bruk av slike virkemidler i Norge i dag - kan det med rimelighet hevdes. Kritikk har også vært reist mot bruk av eksperimentelle metoder for å måle virkninger av tiltak der mekanismene for en eventuell effekt ikke er kjent eller forstått: Det vesentlige er ikke om det virker, men hvorfor, og i hvilken kontekst - vil noen mene (8).

Deler av debatten om verdien av eksperimentelle metoder koker ned til sprikende kunnskapssyn. Det er, for eksempel, vanskelig å forene en oppfatning om at det ikke finnes noen objektiv virkelighet med en tro på at det er mulig å nærme seg "sann" kunnskap om hvorvidt et tiltak virker, eller ei. Det å hevde at resultatene fra eksperimentelle studier bør benyttes av beslutningstakere kan også ses på som "positivistisk" - en ensidig opptatthet av størrelser som kan tallfestes, og manglende forståelse for at økt innsikt og erkjennelse fordrer en mer kvalitativ og fortolkende (hermeneutisk) tilnær- ming (9). Hva er vitsen med å måle virkningene av et tiltak uten samtidig å innhente og fortolke informasjon om hvordan det oppleves å bli utsatt for dette tiltaket?

Men vi kommer ikke utenom at den politiske debatten gjennomsyres av spørsmål og påstander om virkninger av tiltak, og at kunnskap om effekter er noe som etterspørres av dem som utformer politikk (10). Vil gratis p-piller til unge kvinner innvirke på aborttallene? Vi skolefraværet gå ned dersom elevene må ha sykmelding, slik som i arbeidslivet? Bidrar statlig utviklingshjelp til utvikling? Mange av disse spørsmålene er av en slik natur at de belyses best ved hjelp av kvantitative metoder.

\section{Et effektestimat er ikke tilstrekkelig kunnskap}

Dersom et aktuelt tiltak har vært prøvet ut tidligere, og har vært evaluert ved hjelp av eksperimentelle eller kvasi-eksperimentelle metoder, kan det foreligge gode estimater på hva virkningene av tiltaket var. Og dersom det viser seg at tiltaket gjennomgående har virket etter hensikten kan det tyde på at det er verdt å satse på, også hos oss.

Samtidig kan det være meget gode grunner til å ta inn over seg annen forskningsbasert kunnskap enn tallet som beskriver den gjennomsnittlige effekten fra tidligere utprøvninger. Var det variasjon på tvers av de forskjellige studiene med tanke på hvor effektivt tiltaket var? I så fall, hva er de sannsynlige forklaringene på det? Hvilke faktorer var viktige for vellykket iverksetting av tiltaket? Var det noen forhold som bød på særlige utfordringer, og som vi bør ha in mente når det skal implementeres hos oss? Hvordan ble tiltaket opplevd av de involverte partene? Ble det gjennomført kvalitative evalueringer, og avdekket disse noen problemstillinger som vi bør ta høyde for?

\section{Virkning av tiltak som iverksettes}

Det er liten tvil om at mange av de tiltak som iverksettes av myndighetene (regelendringer, reformer osv.), kunne vært testet ved hjelp av eksperimentelle metoder. Det er for eksempel slik at kommunene ofte blir gitt ansvaret for å sette ny politikk ut i live. Det kan la seg gjøre å trekke lodd blant landets kommuner for å avgjøre hvilke som skal innføre tiltaket nå, og hvilke som i denne omgang skal la det være. Etter et år, eller to, eller tre, vil en kunne sammenlikne kommuner med og uten tiltak, og gjøre seg opp en mening om hvorvidt resultatene er bedre i kommunene som iverksatte tiltaket.

En del tiltak er vanskelige å evaluere på denne måten, for eksempel endringer i skatter og avgifter, eller landsdekkende kampanjer. En alternativ tilnærming kan da være å bruke en serie målinger fra periodene før og etter iverksetting av tiltaket (avbrutt tidsserieanalyse).

\section{Dagens praksis $i$ offentlig forvaltning}

Den offentlige forvaltningen er pålagt, både etisk og juridisk, å basere seg på kunnskap i sitt arbeid - inkludert å evaluere virkningene av tiltak som iverksettes: i følge Statens reglement for økonomistyring skal alle virksomheter "sørge for at det gjennomføres evaluerin- 
ger for å få informasjon om effektivitet, måloppnåelse og resultater innenfor hele eller deler av virksomhetens ansvarsområde og aktiviteter" (11). Og i Utredningsinstruksen for Staten understrekes det at virkningene av planlagte tiltak skal vurderes: "Så langt det er mulig skal konsekvensene tallfestes. Det er den samlede effekten av pålagte tiltak, oppgaver og lignende for dem som blir omfattet av forslagene, som skal omtales" (12).

I hvilken grad dette gjøres åpent, systematisk og med bruk av informasjonskilder som holder god kvalitet, er ikke klart. Systematiske oversikter over eksisterende forskning blir sjelden referert til i offentlige utredninger og andre saksdokumenter.

Helseforvaltningen er antakelig den del av offentlig sektor som har kommet lengst med tanke på bruk av forskningsbasert kunnskap i beslutningsprosesser, noe som kan skyldes at forskning tradisjonelt har hatt en viktig plass i helsefagene. For eksempel, da Senter for medisinsk metodevurdering (SMM) ble etablert i 1997 var begrunnelsen blant annet at "Medisinsk teknologivurdering skal fungere som beslutningstøttesystem på klinisk nivå og på samfunnsnivå. Hensikten er selvsagt å oppnå mest mulig helse for fellesskapets midler ved at helsetjenesten benytter seg av metoder med dokumentert effekt" (13).

SMM var én av organisasjonene som seinere ble slått sammen til Nasjonalt kunnskapssenter for helsetjenesten (Kunnskapssenteret). Og begrunnelsen for at Kunnskapssenteret ble etablert i 2004 var nettopp "å styrke beslutningsgrunnlaget for departementet, direktorat og regionale helseforetak for bedre å kunne oppnå helsepolitiske målsetninger og møte fremtidige utfordringer" (14).

Da kvalitetsstrategien for helse- og sosialsektoren (2005-2015) ble utarbeidet stod kunnskapsbasert praksis sentralt, for eksempel i definisjonen av kvalitet: "God kvalitet forutsetter at beslutninger om behandling, forebygging, pleie, omsorg og sosiale tjenester baseres på pålitelig kunnskap om effekt av tiltak" (15).

Siden 2005 har Kunnskapssenteret vært vertskap for det internasjonale sekretariatet til The Campbell Collaboration, som sørger for at det utarbeides systematiske oversikter om tiltak innen utdannings, sosial- og justisfeltet. Og i 2010 vedtok Kunnskapsdepartementet å etablere et Kunnskapssenter for utdanning som "skal formidle forskning som er relevant for senterets målgrupper, blant annet om hva som virker og ikke virker kvalitetsfremmende i barnehage, skole, opplæring og høyere utdanning, ikke minst i praksisfeltet" (16).

\section{HVA ER FORHOLDET MELLOM KUNNSKAP, VERDIVALG OG IDEOLOGI?}

Kunnskapsbasert praksis dreier seg om å integrere den beste tilgjengelige forskning med pasientenes verdier og preferanser og legens kliniske erfaring. På tilsvarende måte kan kunnskapsbasert politikkutforming beskrives som en tilnærming til politiske beslutninger der en søker å benytte den beste, tilgjengelige forskningsbaserte kunnskapen - samtidig som det tas høyde for lokale verdier og preferanser, og utøves politisk skjønn (17). En rekke andre faktorer enn forskningsbasert kunnskap preger politiske beslutningsprosesser. Særinteresser og maktkamp kan være langt viktigere enn fakta når vedtak fattes. Det politiske landskapet preges av forskjeller når det gjelder verdivalg og ideologisk grunnsyn, og dette vil ofte veie langt tyngre enn hva eventuell forskning har vist. Politiske prosesser er sjelden lineære, åpne eller fullt ut forståelige. I hvilken grad politiske beslutningsprosesser er rasjonelle vil også variere. Tidspress, sprikende hensyn, begrensede ressurser og behovet for "å vise handlekraft" kan lede til beslutninger som ikke nødvendigvis er de beste.

Selv om politiske prosesser av natur er kompliserte og sjelden helt transparente, bør forskningsbasert kunnskap kunne tas inn som en del av beslutningsgrunnlaget på en åpen og systematisk måte. Dette betyr ikke at de politiske prosessene i seg selv må være systematiske og transparente. Men bruken av kunnskap som del av beslutningsgrunnlaget bør kunne være systematisk og transparent.

Det er viktig å erkjenne at forskningsbasert kunnskap kun er én av mange faktorer som kan innvirke på politiske beslutninger, og at det samme kunnskapsgrunnlaget kan lede til motstridende konklusjoner, avhengig av ideologisk ståsted, verdimessige vurderinger, kontekst osv. Men mer og bedre bruk av forskning kan medføre en rekke fordeler for politikere og andre som er involvert i politiske beslutninger (17):

- De kan lettere stille kritiske spørsmål om kunnskapsgrunnlaget for de tiltak som blir foreslått (også fra politiske motstandere)

- De kan vise til kunnskapsgrunnlaget for tiltak de selv foreslår

- De kan sørge for egnet evaluering av tiltak som iverksettes

Det er ofte uklart hvorvidt de motstridende standpunkt som forfektes i den politiske debatten skyldes sprikende virkelighetsoppfatninger - for eksempel om omfanget av et problem eller om et tiltak kan forventes å ha en effekt - eller ideologiske motsetninger. Transparent og systematisk bruk av forskningsbasert kunnskap kan gjøre dette skillet tydeligere, og bidra til en mer konstruktiv politisk debatt.

\section{Interessekonflikt}

Atle Fretheim arbeider ved Nasjonalt kunnskapssenter for helsetjenesten, som er etablert for å bidra til økt bruk av forskningsbasert kunnskap i helsetjenesten. 


\section{REFERANSER}

1. Evidence-based medicine. A new approach to teaching the practice of medicine. JAMA 1992; 268: 2420-5.

2. Sackett DL, Straus SE, Richardson WS, Rosenberg W, Haynes BR. Evidence-based medicine. How to practice and teach EBM, 2nd edn. London: Churchill Livingstone, 2000.

3. Lavis JN, Wilson MG, Oxman AD, Lewin S, Fretheim A. SUPPORT Tools for evidence-informed health Policymaking (STP) 4: Using research evidence to clarify a problem. Health Res Policy Syst 2009; 7 Suppl 1: S4.

4. Lewin S, Oxman AD, Lavis JN, Fretheim A, Garcia MS, Munabi-Babigumira S. SUPPORT tools for evidence-informed policymaking in health 11: Finding and using evidence about local conditions. Health Res Policy Syst 2009; 7 Suppl 1: S11.

5. Lavis JN, Wilson MG, Oxman AD, Grimshaw J, Lewin S, Fretheim A. SUPPORT Tools for evidenceinformed health Policymaking (STP) 5: Using research evidence to frame options to address a problem. Health Res Policy Syst 2009; 7 Suppl 1: S5.

6. Victora CG, Habicht JP, Bryce J. Evidence-based public health: moving beyond randomized trials. Am J Public Health 2004; 94: 400-5.

7. Hammersley M. Is the evidence-based practice movement doing more good than harm? Reflections on Iain Chalmers' case for research-based policy making and practice. Evidence \& Policy 2005; 1: 85-100.

$\begin{array}{llll}\text { 8. Eikeland TJ. Evidensbasert toalettrening. } & \text { Morgenbladet, } & \text { 21.09.2007. }\end{array}$ http://176.58.98.57/debatt/2007/evidensbasert_toalettrening (09.04.2013).

9. Holmes D, Murray SJ, Perron A, Rail G. Deconstructing the evidence-based discourse in health sciences: truth, power and fascism. Int J Evid Based Healthc 2006; 4: 180-6.

10. Innvaer S, Vist G, Trommald M, Oxman A. Health policy-makers' perceptions of their use of evidence: a systematic review. J Health Serv Res Policy 2002; 7: 239-44.

11. Reglement for økonomistyring i Staten, §16 Evaluering, 2003. www.lovdata.no/cgi-wift/ldles?doc=/sf/sf/sf20031212-1938.html (17.09.2013).

12. Instruks om utredning av konsekvenser, foreleggelse og høring ved arbeidet med offentlige utredninger, forskrifter, proposisjoner og meldinger til Stortinget, 2000. http://www.lovdata.no/cgiwift/ldles?doc=/sf/sf/sf-20000218-0108.html (17.09.2013).

13. Norges offentlige utredninger. Omsorg og kunnskap! NOU 1997: 20.

14. St.prp. nr. 1 (2003-2004). http://www.regjeringen.no/nb/dep/hod/dok/regpubl/stprp/20032004/stprp-nr-12003-2004-/8/2/4.html?id=296547 (17.09.2013).

15. ...og bedre skal det bli! - Nasjonal strategi for kvalitetsforbedring i Sosial- og helsetjenesten (2005-2015). Oslo: Sosial- og helsedirektoratet, 2005.

16. Oppdragsbrev til Norges forskningsråd om Kunnskapssenter for utdanning, Det Kongelige Kunnskapsdepartement, 2010.

17. Oxman AD, Lavis JN, Lewin S, Fretheim A. SUPPORT Tools for evidence-informed health Policymaking (STP) 1: What is evidence-informed policymaking? Health Res Policy Syst 2009; 7 Suppl 1: S1. 